\title{
Further Commentary on Pam Reynolds's NDE
}

To the Editor:

I am writing in response to the recent debate in this Journal between Keith Augustine and the near-death researchers, and in particular the treatment of the Pam Reynolds case (Augustine, 2007a, 2007b; Sabom, 2007; Tart, 2007). Please allow me the opportunity to express my astonishment that not one word was devoted to the comments that neurosurgeon Robert Spetzler made in the British Broadcasting Corporation documentary The Day I Died (Broome, 2002).

Spetzler's comments are of paramount importance. After all, it was Spetzler who operated upon Reynolds. Gerald Woerlee, on whose ideas Augustine mainly based his judgments, was not there. Nevertheless, Woerlee bluntly wrote that Reynolds had been awake ("aware" as he told me in an Internet blog) and thus could have seen and heard everything she recounted afterwards (Woerlee, 2003, 2005; http:// www.mortalminds.woerlee.org/reynolds.html). But based on Spetzler's comments, I think we can safely assume that Woerlee's and Augustine's assumptions are just that: assumptions not based on fact.

Regarding whether Reynolds had "seen" several gadgets in the operating room, Spetzler said:

I don't think the observations she made were based on what she experienced when she went into the operating theatre. They were just not available to her. For example, the drill and so on were covered up and invisible. They were inside their packages. 
The packages in which the drill and other equipment were stored would not have been opened before the operation, and in any event Reynolds's eyes were taped shut. Regarding Reynolds's hearing the conversation between Spetzler and the cardiac surgeon, he said:

At that stage of the operation nobody can observe or hear in that state. I find it inconceivable that your normal senses such as hearing, let alone the fact that she had clicking modules in each ear, that there was any way for her to hear those through the normal auditory pathways.

In summarizing this case, Spetzler declared:

I don't have an explanation for it. I don't know how it is possible for it to happen considering the physiological state she [was] in. At the same time I have seen so many things that I cannot explain that I won't be so arrogant to say that there is no way that it can happen.

Spetzler, who performed the operation, showed his greatness of mind by admitting that he did not know. Woerlee and Augustine, however, who were not there when the surgery was performed, were indeed so arrogant as to forward a mere speculation as truth. When I told this to Woerlee he retorted that Spetzler, as a surgeon, would not have known about the phenomenon of "awareness during anesthesia." Now it is my turn to find that inconceivable, that a pioneering neurosurgeon such as Robert Spetzler would not have known of this phenomenon that is taught to all surgeons and surgery assistants.

\section{References}

Augustine K. (2007a). Does paranormal perception occur in near-death experiences? Journal of Near-Death Studies, 25, 203-236.

Augustine K. (2007b). "Does paranormal perception occur in near-death experiences?" defended. Journal of Near-Death Studies, 25, 261-283.

Broome K. (Producer). (2002). The day I died: The mind, the brain, and neardeath experiences [videorecording]. London, England: British Broadcasting Corporation.

Sabom M. B. (2007). Commentary on "Does paranormal perception occur in near-death experiences?" Journal of Near-Death Studies, 25, 257-260.

Tart C. T. (2007). Commentary on "Does paranormal perception occur in neardeath experiences?" Journal of Near-Death Studies, 25, 251-256.

Woerlee G. M. (2003). Mortal minds: A biology of the soul and the dying experience. Utrecht, The Netherlands: de Tijdstroom. 
Woerlee G. W. (2005). Cardiac arrest and near-death experiences: Woerlee responds. Journal of Near-Death Studies, 25, 187-194.

Rudolf H. Smit

Editor, Terugkeer

The Merkawah Foundation (IANDS the Netherlands)

Goudplevierstraat 87

$8043 \mathrm{JJ}$ Zwole, The Netherlands

e-mail: rhs@rudolfsmit.nl 